\title{
Neonatal presentation of PHACE syndrome
}

\author{
James Williams, ${ }^{1}$ Terry Cullen, ${ }^{1}$ Karen L Atkin, ${ }^{2}$ Ruth K Armstrong ${ }^{1}$
}

'Department of Neonatal Medicine, The Royal Children's Hospital, Melbourne, Victoria, Australia

${ }^{2}$ Department of Radiology, The Royal Children's Hospital, Melbourne, Victoria, Australia

\section{Correspondence to} Dr Terry Cullen;

tdcullen@hotmail.co.uk

Accepted 6 June 2021

\section{DESCRIPTION}

The surviving female monochorionic, diamniotic twin of an in vitro fertilisation assisted pregnancy complicated by prolonged rupture of membranes, chorioamnionitis and antepartum haemorrhage, was delivered at 24 weeks' gestation, weighing 706 grams following spontaneous preterm labour. Antenatal steroids were incomplete. She was intubated at birth, with Apgar scores of 7 at 1 minute, 9 at 5 minutes, and 10 at 10 minutes.

Mechanical ventilation was required for 36 days. Two courses of steroids, from day 11 to 21 and 26 to 36 (DART regimen), ${ }^{1}$ were required to facilitate extubation to continuous positive airway pressure for the following 36 days. A third course of steroids (Cummings' regimen) ${ }^{2}$ from day 36 to 72 enabled transition to low flow subnasal oxygen. Hypothyroidism required thyroxine treatment from day 100 of life. Retinopathy of prematurity was treated with intravitreal bevacizumab and laser therapy.

Multiple cutaneous haemangiomas evolved over 15 weeks with marked proliferation following cessation of steroids (figure 1). A scheduled cerebral MRI at term corrected gestational age prompted urgent transfer to a tertiary referral centre for specialist assessment (day 116 of life).

Abdominal ultrasound and cerebral, neck and thoracic MRI determined extensive internal disease with multiple haemangiomas shown to be compressing and deviating the brainstem and large multilobulated neck haemangiomas extending into

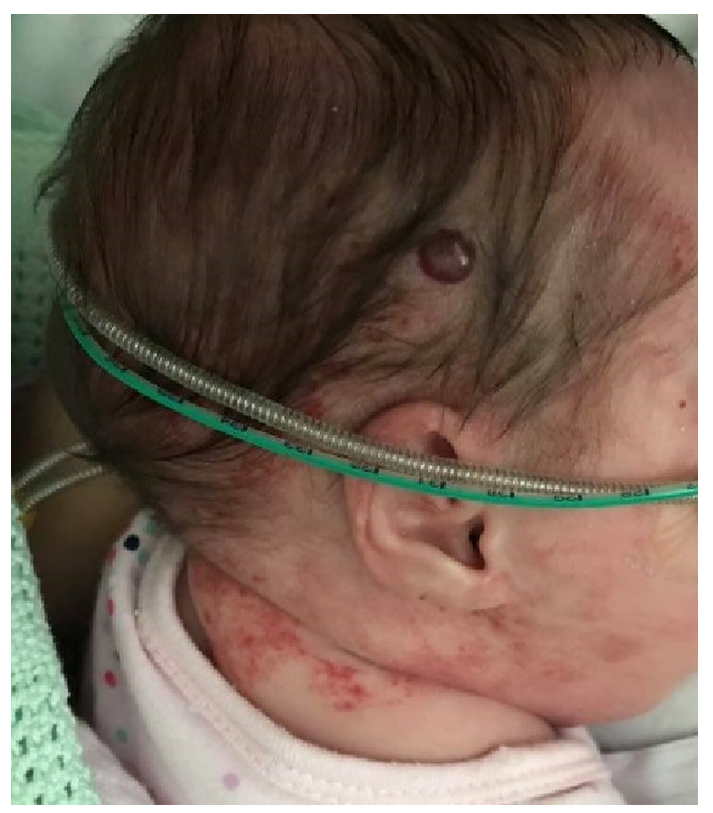

Figure 1 Haemangiomas visible over the right parietooccipital and the posterior cervical regions.

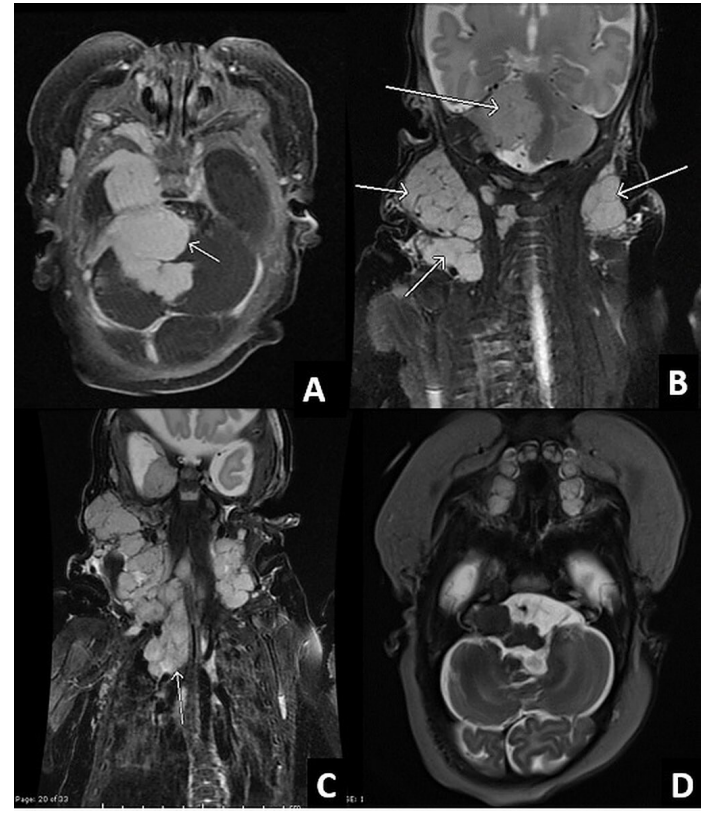

Figure 2 Cerebral, neck and thoracic MRI (A) Axial T1 postcontrast MRI of the posterior fossa demonstrating the avidly enhancing haemangioma centred on the right cerebellopontine angle, compressing the brainstem (arrow) and extending into the right middle cranial fossa. (B) Coronal T2 fat-saturated MRI of the head and neck demonstrating the right posterior fossa haemangioma causing brainstem compression and bilateral neck haemangiomas. (C) Coronal T2 fat-saturated MRI of the head and neck demonstrating the extent of the bilateral neck haemangiomas extending inferiorly into the mediastinum (arrow). (D) Follow-up MRI performed at 4 months of age. Axial T2 sequence demonstrating a significant reduction in size of the posterior fossa haemangioma with treatment.

the mediastinum, and encasing and compressing the trachea and oesophagus. (figure 2A-C). Rapid progression in growth of the lesions over the subsequent 2 days resulted in critical airway obstruction and hypotension, requiring intubation and vasopressor support. Treatment targeting regression of the haemangiomas was commenced using pulsed-dose steroids, interferon and propranolol and is detailed in table 1. Large fluctuations in blood pressure complicated this treatment, most likely due to a combination of factors involving medication effects, systemic steal phenomenon and compression of both the superior vena cava and brainstem. Over the subsequent 44 days, visible involution of cutaneous haemangiomas was accompanied by symptomatic recovery and a further MRI confirmed accompanying involution 
Table 1 Summary of medical treatment to reduce mass effect of capillary haemangiomas from day 116 of life

\begin{tabular}{lll}
\hline Drug, route & Dose, frequency & Duration of treatment (days of life) \\
\hline Propranolol PO & $1 \mathrm{mg} / \mathrm{kg}$ three times a day & 116 -ongoing, aged 10 months \\
\hline Methylprednisolone intravenously & $30 \mathrm{mg} / \mathrm{kg}$ OD & $118-121$ \\
Interferon alpha 2a S/C & 3 million subunits OD & $119-156$ \\
Prednisolone intravenously & $2 \mathrm{mg} / \mathrm{kg}$ OD & $121-134$ \\
\hline Hydrocortisone PO & $3 \mathrm{mg} / \mathrm{kg}$ OD & $135-160$ \\
\hline
\end{tabular}

$\mathrm{OD}$, once daily; $\mathrm{PO}$, orally; $\mathrm{S} / \mathrm{C}$, subcutaneous.

of internal haemangiomas with significant reduction in mass effect (figure 2D).

PHACE (Posterior fossa malformations, haemangioma, arterial anomalies, coarctation of the aorta/cardiac defects and eye abnormalities) syndrome (table 2) was confirmed on MRI angiography by the demonstration of variant arterial anatomy

\begin{tabular}{|c|c|c|}
\hline Organ systems & Major criteria & Minor criteria \\
\hline Arterial anomalies & $\begin{array}{l}\text { Anomaly of major cerebral or cervical } \\
\text { arteries * }+ \\
\text { Dysplasia } \ddagger \text { of the large cerebral arteries } \\
\text { Arterial stenosis or occlusion with } \\
\text { or without Moyamoya collaterals } \\
\text { Absence or moderate to severe } \\
\text { hypoplasia of the large cerebral } \\
\text { and cervical arteries } \\
\text { Aberrant origin or course of the } \\
\text { large cerebral or cervical arteries } \\
\text { except common arch variants such } \\
\text { as bovine arch } \\
\text { Persistent carotid-vertebrobasilar } \\
\text { anastomosis (proatlantal } \\
\text { segmental, hypoglossal, otic and/or } \\
\text { trigeminal arteries) }\end{array}$ & $\begin{array}{l}\text { Aneurysm of any of the } \\
\text { cerebral arteries }\end{array}$ \\
\hline Structural brain & $\begin{array}{l}\text { Posterior fossa brain anomalies } \\
\text { Dandy-Walker complex } \\
\text { Other hypoplasia/dysplasia of the } \\
\text { mid and/or hind brain }\end{array}$ & $\begin{array}{l}\text { Midline brain anomalies } \\
\text { Malformation of cortical } \\
\text { development }\end{array}$ \\
\hline Cardiovascular & $\begin{array}{l}\text { Aortic arch anomalies } \\
\text { Coarctation of the aorta } \\
\text { Dysplasia* } \\
\text { Aneurysm } \\
\text { Aberrant origin of the subclavian } \\
\text { artery with or without a vascular } \\
\text { ring }\end{array}$ & $\begin{array}{l}\text { Ventricular septal defect } \\
\text { Right aortic arch/double } \\
\text { aortic arch } \\
\text { Systemic venous anomalies }\end{array}$ \\
\hline Ocular & $\begin{array}{l}\text { Posterior segment abnormalities } \\
\text { Persistent hyperplastic primary } \\
\text { vitreous } \\
\text { Persistent fetal vasculature } \\
\text { Retinal vascular anomaliest } \\
\text { Morning glory disc anomaly } \\
\text { Optic nerve hypoplasia } \\
\text { Peripapillary staphyloma }\end{array}$ & $\begin{array}{l}\text { Anterior segment } \\
\text { abnormalities } \\
\text { Microphthalmia } \\
\text { Sclerocornea } \\
\text { Coloboma } \\
\text { Cataracts }\end{array}$ \\
\hline Ventral/midline & $\begin{array}{l}\text { Anomaly of the midline chest and } \\
\text { abdomen } \\
\text { Sternal defect } \\
\text { Sternal pit } \\
\text { Sternal cleft } \\
\text { Supraumbilical raphe }\end{array}$ & $\begin{array}{l}\text { Ectopic thyroid } \\
\text { hypopituitarism } \\
\text { Midline sternal papule/ } \\
\text { hamartoma }\end{array}$ \\
\hline
\end{tabular}

Definite PHACE

Haemangioma $>5 \mathrm{~cm}$ in diameter of the head, including scalp plus one major criteria or two minor criteriat

Haemangioma of the neck, upper trunk or trunk and proximal upper extremity Plus two major criteria

\section{Possible PHACE}

Haemangioma $>5 \mathrm{~cm}$ Haemangioma of the neck, upper trunk No haemangioma in diameter of the head or trunk and proximal upper extremity Plus two major criteria including scalp plus one minor criteria

*Internal carotid artery, middle cerebral artery, anterior cerebral artery, posterior cerebral artery o vertebrobasilar system

tDiagnostic criteria present in this patien

łIncludes kinking, looping, tortuosity and/or dolichoectasia

PHACE, posterior fossa malformations, hemangioma, arterial anomalies, coarctation of the aorta/ cardiac defects and eye abnormalities.

\section{Patient's perspective}

Our daughter had a very tough start to life and we endured the usual ups and downs that came with the neonatal intensive care unit and having a baby born at 24 weeks' gestation. Just as we were turning a corner and were told we were close to going home, our daughter's scheduled term MRI revealed our worst nightmare. We had noticed some of the external birthmarks growing on her face and neck, but had not heard of posterior fossa malformations, haemangioma, arterial anomalies, coarctation of the aorta/cardiac defects, and eye abnormalities before and had no idea how serious her condition was. The MRI showed that she had haemangiomas everywhere internallybehind her eyes, protruding on her brain, spine and trachea. We were told she may not make it and were crushed. The medical team immediately began many doses of different drugs, all with different side effects, which may or may not impact her in the future, and we were given a 2-week deadline for the drugs to work, otherwise there was nothing more that could be done. After the 2 weeks, we had another MRI and were thankful that the drugs had worked - most of the haemangiomas had shrunk and some had even disappeared altogether.

\section{Learning points}

- Multiple cutaneous haemangiomas warrant consideration of more extensive disease, for example, hepatic or intracerebral.

- Investigations for hypothyroidism should occur. Presence may indicate more extensive or multisite disease, which is due to consumption of thyroxine within the lesion(s), and must be treated - often requiring higher than usual doses of thyroxine.

- Posterior fossa malformations, haemangioma, arterial anomalies, coarctation of the aorta/cardiac defects and eye abnormalities (PHACE) or PHACES association is a neurocutaneous disorder.

- Rapidly enlarging haemangiomas surrounding the brainstem and airway can be life-threatening and may respond rapidly to treatment with pulsed steroids and interferon.

with hypoplasia of both the right vertebral artery and right anterior cerebral artery (A1 segment), and tortuosity of the internal carotid arteries.

Extubation via non-invasive ventilation to low-flow oxygen to manage her chronic lung disease was successful on day 158 of life. Duration of propranolol treatment will be determined by follow-up MRI over the next 12-24 months.

Acknowledgements We would like to acknowledge Dr Rod Phillips for his expertise and contribution to this patient's care and support for this manuscript.

Contributors JW wrote the first draft of the manuscript. TC devised the article and reviewed the manuscript. KLA provided the radiology images and accompanying text. RKA was in charge of the treatment, and oversaw the re-drafts of the manuscript.

Funding The authors have not declared a specific grant for this research from any funding agency in the public, commercial or not-for-profit sectors.

Competing interests None declared.

Patient consent for publication Obtained.

Provenance and peer review Not commissioned; externally peer-reviewed. 


\section{REFERENCES}

1 Doyle LW, Davis PG, Morley CJ, et al. Low-dose dexamethasone facilitates extubation among chronically ventilator-dependent infants: a multicenter, international, randomized, controlled trial. Pediatrics 2006;117:75-83.
2 Cummings JJ, D'Eugenio DB, Gross SJ. A controlled trial of dexamethasone in preterm infants at high risk for bronchopulmonary dysplasia. N Engl J Med 1989;320:1505-10.

3 Garzon MC, Epstein LG, Heyer GL, et al. PHACE syndrome: Consensus-Derived diagnosis and care recommendations. J Pediatr 2016;178:24-33.

Copyright 2021 BMJ Publishing Group. All rights reserved. For permission to reuse any of this content visit

https://www.bmj.com/company/products-services/rights-and-licensing/permissions/

BMJ Case Report Fellows may re-use this article for personal use and teaching without any further permission.

Become a Fellow of BMJ Case Reports today and you can:

- Submit as many cases as you like

- Enjoy fast sympathetic peer review and rapid publication of accepted articles

- Access all the published articles

- Re-use any of the published material for personal use and teaching without further permission

\section{Customer Service}

If you have any further queries about your subscription, please contact our customer services team on +44 (0) 2071111105 or via email at support@bmj.com.

Visit casereports.bmj.com for more articles like this and to become a Fellow 